\title{
Quarterly Environmental Radiological Survey Summary
}

Third Quarter 1997

$100,200,300$, and 600 Areas

B. M. Markes

S. M. McKinney

Waste Management Federal Services, Northwest Operations

Date Published

October 1997

Prepared for the U.S. Department of Energy

Assistant Secretary for Environmental Management 
LEGAL DISCLAIMER

This report was prepared as an account of work sponsored by an agency of the United States Government. Neither the United States Government nor any agency thereof, nor any of their employees, nor any of theit contractors, subcontractors or their employees, makes any warranty, express or implied, or assumes any legal liability or responsibility for the accuracy, completeness, or any third party's use or the results of such use of any information, apparatus, product, or process disclosed, or represents that its use would not infringe privately owned rights. Reference herein to any specific commercial product, process, or service by trade name, trademark, manufacturer, or otherwise, does not necessarily constitute or imply its endorsement, recommendation, or favoring by the United States Government or any agency thereof or its contractors or subcontractors. The views and opinions of authors expressed herein do not necessarily state or reflect those of the United States Government or any agency thereof.

This report has been reproduced from the best available copy. Available in paper copy and microfiche.

Available to the U.S. Department of Energy and its contractors from

Office of Scientific and Technical Information

P.O. Box 62

Oak Ridge, TN 37831

(615) $576-8401$

Available to the public from the U.S. Department of Commerce National Technical Information Service

5285 Port Royal Road

Springfield, VA 22161

(703) 487.4650

Printed in the United States of America

DISCLM-1.CHP (1-91) 
HNF-SP-0665-26

APPROVAL PAGE

PREPARED BY

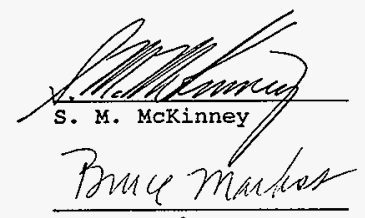

B. M. Markes
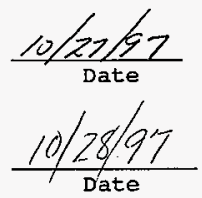

REVIEWED BY

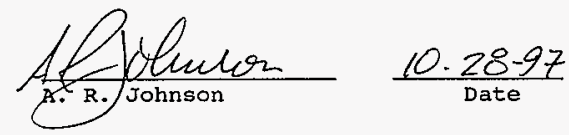

APPROVED BY:

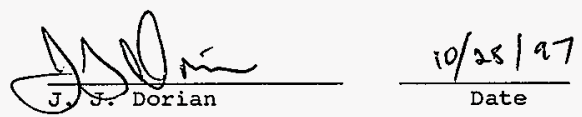




\section{EXECUTIVE SUMMARY}

This report provides a summary of the radiological surveys performed in support of near-facility environmental monitoring at the Hanford site. The Third Quarter 1997 survey results and the status of actions required are summarized below:

- All of the routine environmental radiological surveys scheduled during July, August, and september, were performed as planned with the exception of REDox rail road cut. This site was not surveyed due to physical constraints. The siteg switched during the second quarter for the Environmental Restorations Contractor (ERC) team were completed during the third quarter.

- One hundred thirty three environmental radiological surveys were performed during the third quarter 1997, 33 at the active waste sites and 100 at the inactive waste sites. Contamination above background levels was found at four of the active waste sites and five of the inactive waste sites. Contamination levels as high 600,000 disintegrations per minute (dpm) were reported. Of these contaminated surveys . five were in Underground Radioactive Material (URM) areas and four were in contamination areas. The contamination found within three of the URM areas was immediately cleaned up and no further action was required. The remaining two URM sites were posted and will require decontamination. Radiological Problem Reports (RPR's) were issued and the sites were turned over to the landlord for further action as required.

- During the third quarter of 1997, 2.0 hectares (5.0 acres) were stabilized and radiologically down posted from Contamination Area (CA)/Soil Contamination (SC) to URM.

- Five open surveillance compliance Inspection Reports (SCIRs) had not been regolved.

Responsibilities for the unresolved SCIRs are as follows:

LANDLORD

Tank Farm Operations (TFO)

Solid Waste Operations (SwO)
OPEN SCIR/CAR

4

1 
Below is a listing of the top ten waste sites in order of highest priority ranking for contamination control. The waste site may have an open SCIR of CAR identifying the contamination. An explanation of the prioritization system is on page 13 of this report.

\section{SITE}

1. 241-C Tank Farm Perimeters

2. 241-B Tank Farm Perimeters

3. 241-BX-BY Tank Farm Perimeters

4. 241-S, SX, SY Tank Farm Perimeters

5. UN-216-E-6 241-BX-155 Diversion BoX

6. 207-U Retention Basin

7. 216-B-64 Basin

8. 207-A Retention Basin

9. 207-B Retention Basin

10. 241-A Tank Farm

\section{CUSTODIAN}

TFO

TFO

TFO

TFO

TFO

ERC

B-plant

TFO

B-Plant

TFO
SCIR/CAR

9008EP200-068

8909EP200-036

9007EP200-056

9208ERI-006

NONE

NONE

NONE

NONE

NONE

NONE 
HNF-SP-0665-26

TABLE OF CONTENTS

EXECUTIVE SUMMARY ............... i

TOP TEN PRIORITY RANKING ................ i i

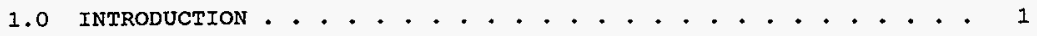

AREA RADIOLOGICAL CONTAMINATION ILLUSTRATIONS $\ldots . .2-11$

TABLE 1, OPEN SCIRs AND CARs .................. 12

2.0 PROGRAM DESCRIPTION ......................... 13

2.1 ENVIRONMENTAE RADIOLOGICAL SURVEY OBJECTIVES . . . . . . 13

2.2 PRIORITY RANKING SYSTEM . . . . . . . . . . . . . 13

2.3 ENVIRONMENTAL STANDARDS . . . . . . . . . . . . . . 14

2.4 SURVEY METHODS AND PROCEDURES . . . . . . . . . . . . 16

2.4 .1 ROAD/RAILROAD SURVEYS . . . . . . . . . 16

2.4.2 WASTE SITES AND OTHER RADIOLOGICAL AREA SURVEYS • • 16

3.0 RADIOLOGICAL SURVEY RESULTS . . . . . . . . . 17

3.1 ENVIRONMENTAL RADIOLOGICAL SURVEY SUMMARY . . . . . . 17

table 2, 1996 contamination Samples . . . . . . . . . . . . .

3.2 COMPLIANCE/SURVEILLANCE REPORTS CLOSED . . . . . . 22

3.3 STATUS OF OPEN SURVEILLANCE AND COMPLIANCE REPORTS . . . 22

4.0 sUMMARY $\ldots \ldots \ldots . \ldots \ldots$

TABLE 3, OUTDOOR CONTAMINATION STATUS ........... 24 


\subsection{INTRODUCTION}

Routine radiological surveys are part of near-facility environmental monitoring which monitors and helps direct the reduction of the radiological areas at the Hanford site. The routine radiological surveys are performed by the Southern Area Remediation Support Group and the site support Services Radiological Control Group as directed by Environmental Monitoring and Investigations. The surveys included in this program consist of inactive waste sites; outdoor radiological control areas; tank farm perimeters and associated diversion boxes, lift stations, and vent stations; perimeters of active or uncovered waste sites such as burial grounds, retention basins, ponds, process trenches, and ditches; underground pipelines; and road and rail surfaces (Figures 1 through 10). This report provides a summary of the radiological surveys performed during the Third quarter of 1997. The status of corrective actions required from current and past reports are also discussed.

A waste site survey schedule, WHC-SP-0098-8, was developed by Environmental Monitoring and Investigations and reviewed by the southern Area Remediation support Group and the site support Services Radiological control Group. Environmental Monitoring and Investigations reviews the radiological survey reports and files a copy for historical purposes and reference. Radiological conditions are tracked and trends noted. All sites are surveyed at least once each year. The survey frequencies for particular sites are based on site history, radiological conditions, and general maintenance. special surveys may be conducted at irregular frequencies if conditions warrant $(\mathrm{e} . \mathrm{g} .$, growth of deep-rooted vegetation is noted at a waste site). Radiological surveys are conducted to detect surface contamination and document changes in vegetation growth, biological intrusion, erosion, and general site maintenance conditions. Survey data are compared with standards identified in WHC-CM-7-5, Environmental Compliance, as well as previous surveys to recognize possible trends, assess environmental impacts, and help determine where corrective actions are needed.

Landlords of the sites found out of compliance may be issued a Radiological Problem Report (RPR) from the appropriate radiological Control Group. Open Surveillance Compliance Inspection Reports (SCIRs) and Compliance Assessment Reports (CARs) are listed in Table 1 of this report.

The surveys scheduled for this program consist of inactive waste sitea; outdoor radiological areas; tank farm perimeters and associated diversion boxes, lift stations, and vent stations; perimeters of active or uncovered waste sites such as burial grounds, retention basins, ponds, process trenches, and ditches; underground pipelines; and road and rail surfaces. Surveillance of the active nuclear facilities and inside the tank farms is the responsibility of the facility. These radiological surveys are to determine surface radiological conditions and do not constitute a release survey. Therefore, surveys that detect no contamination in radiological areas do not release the site from control. but may regult in a posting status change. 


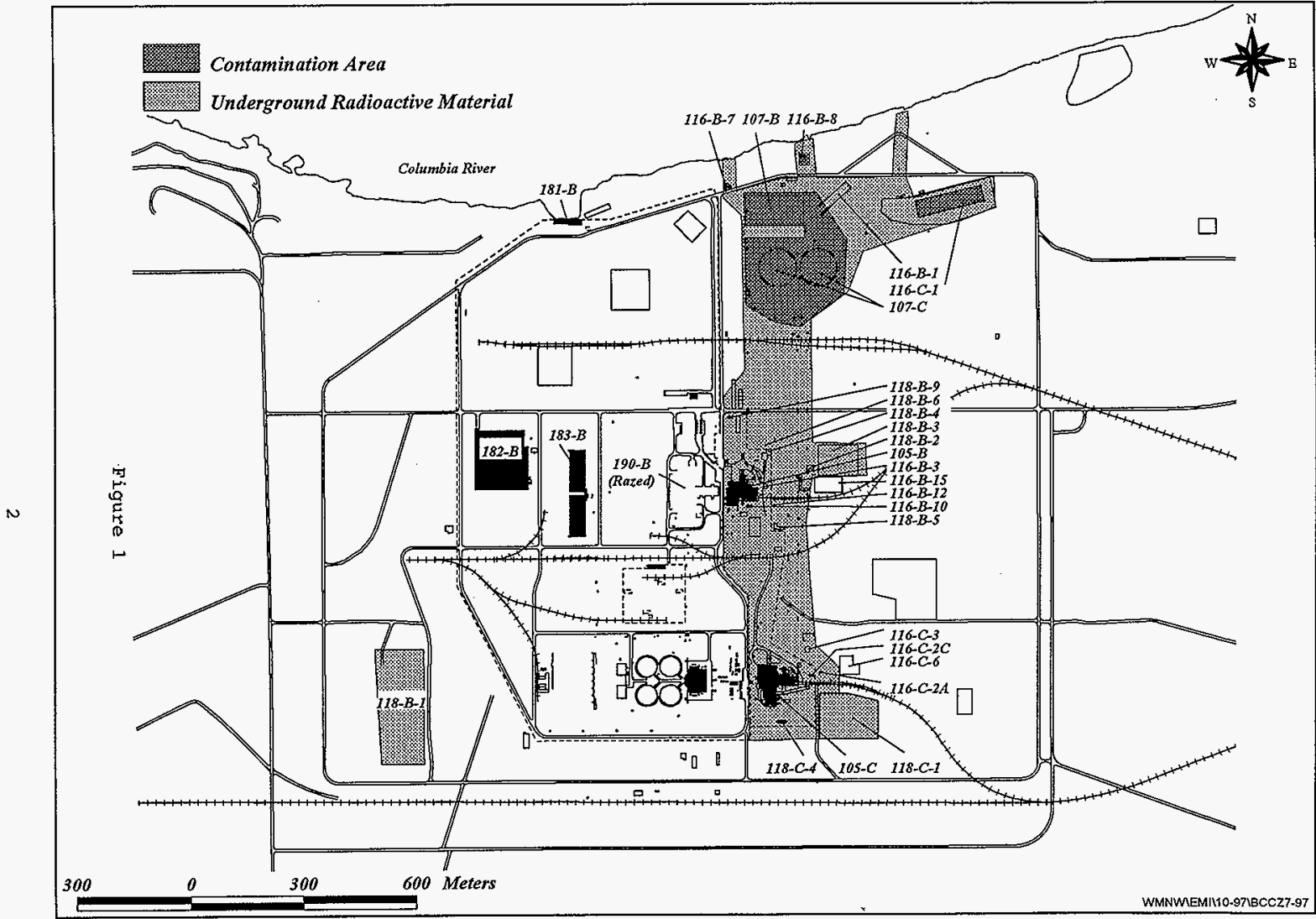




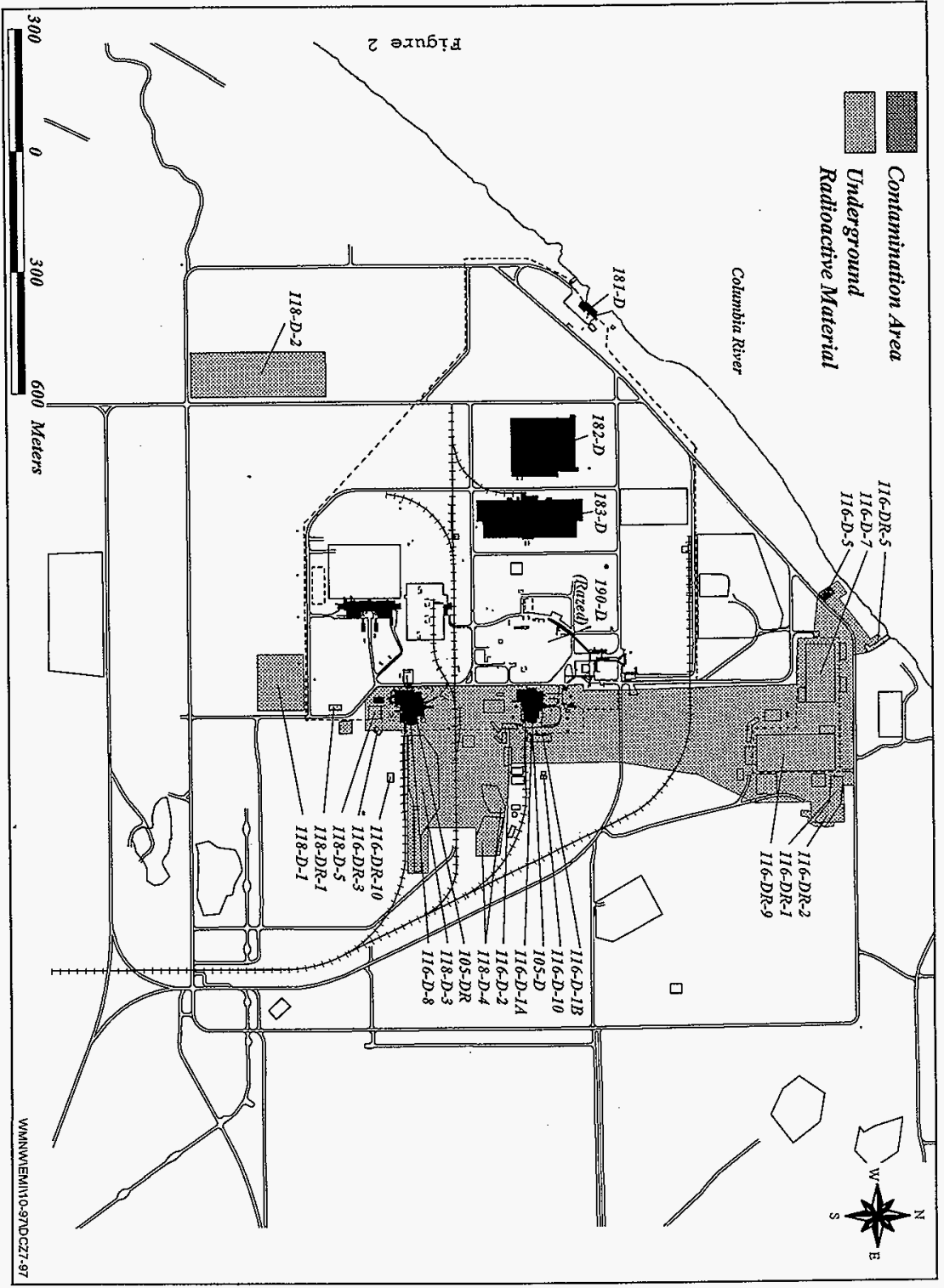




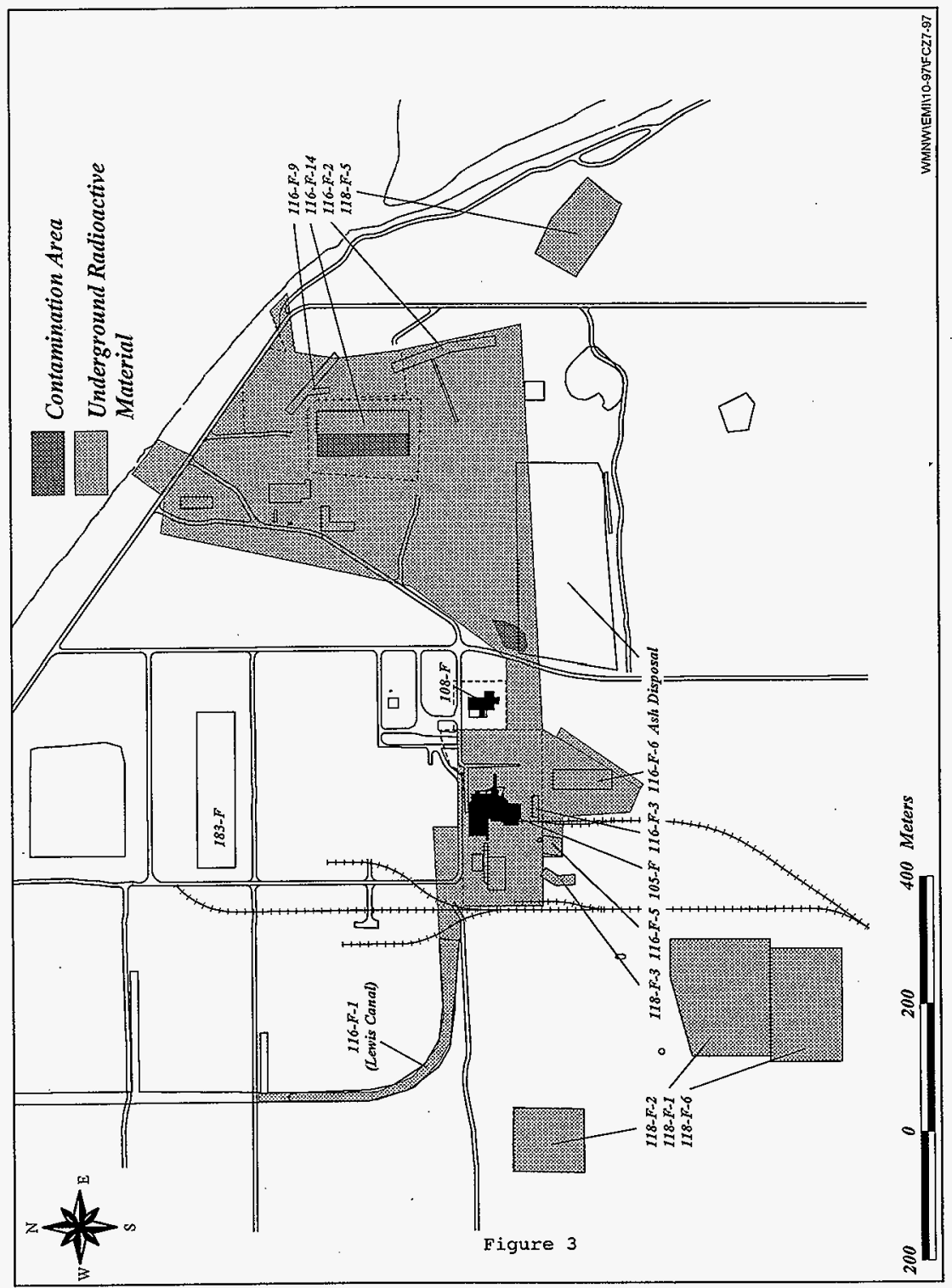




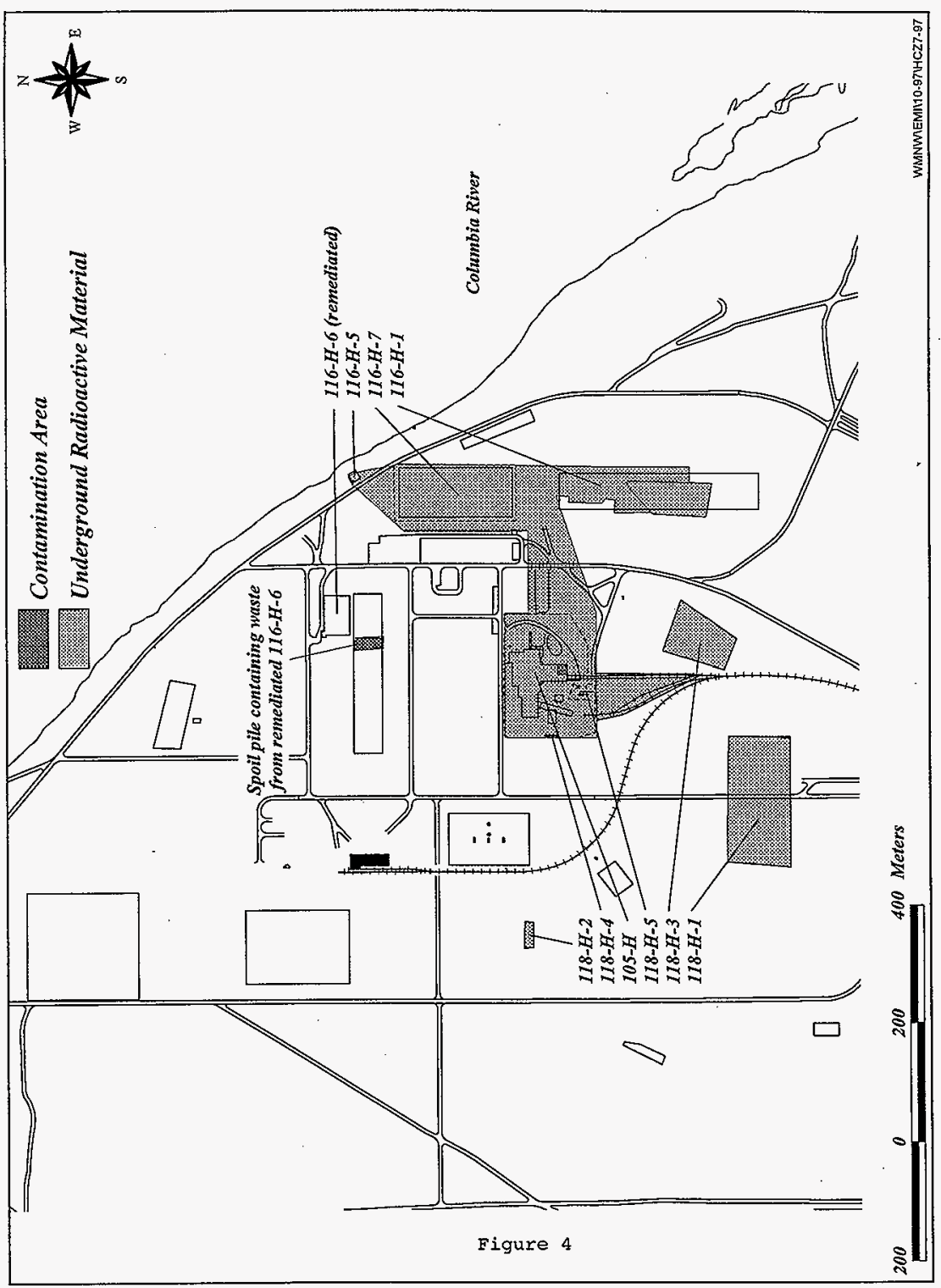




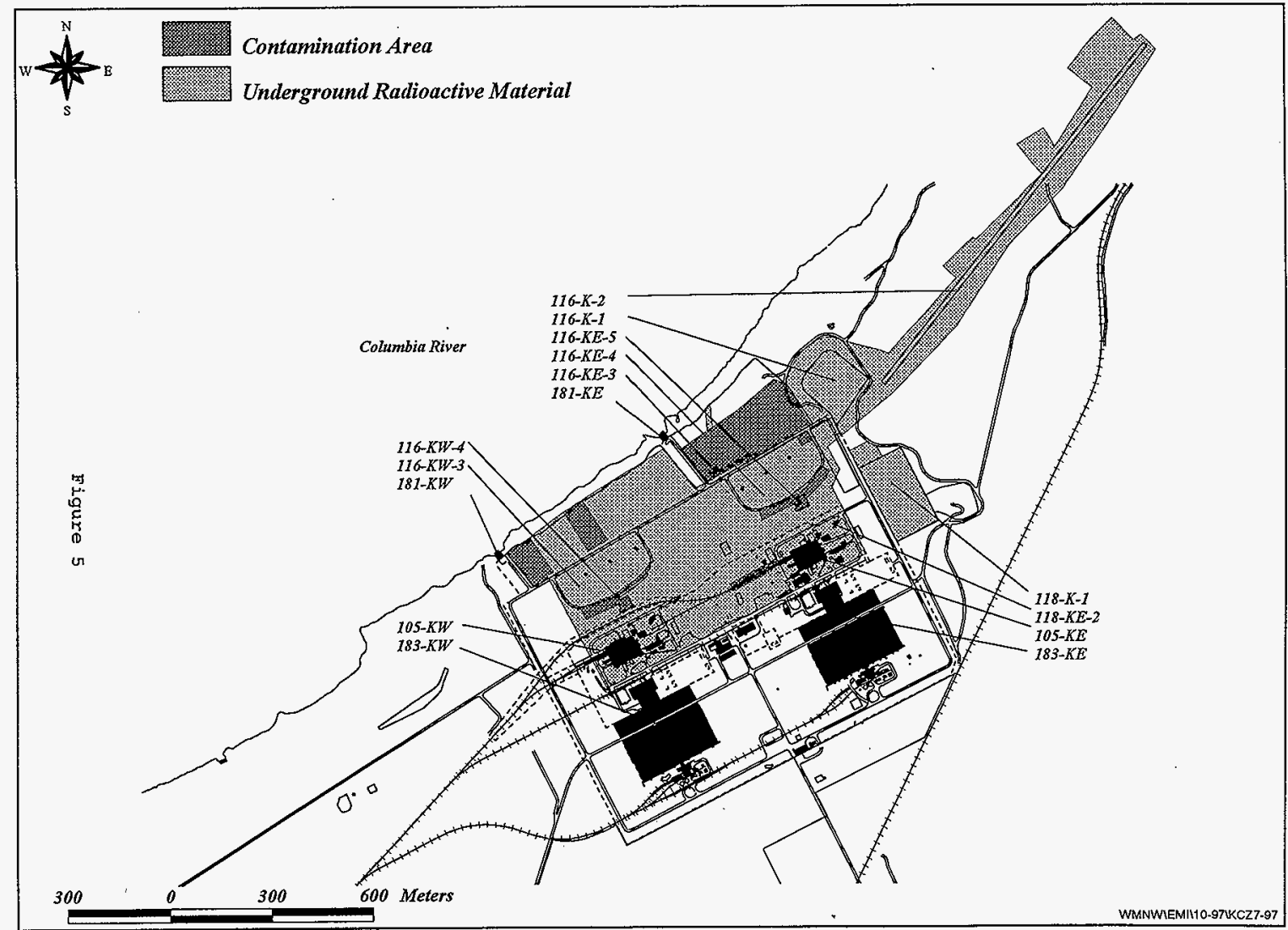









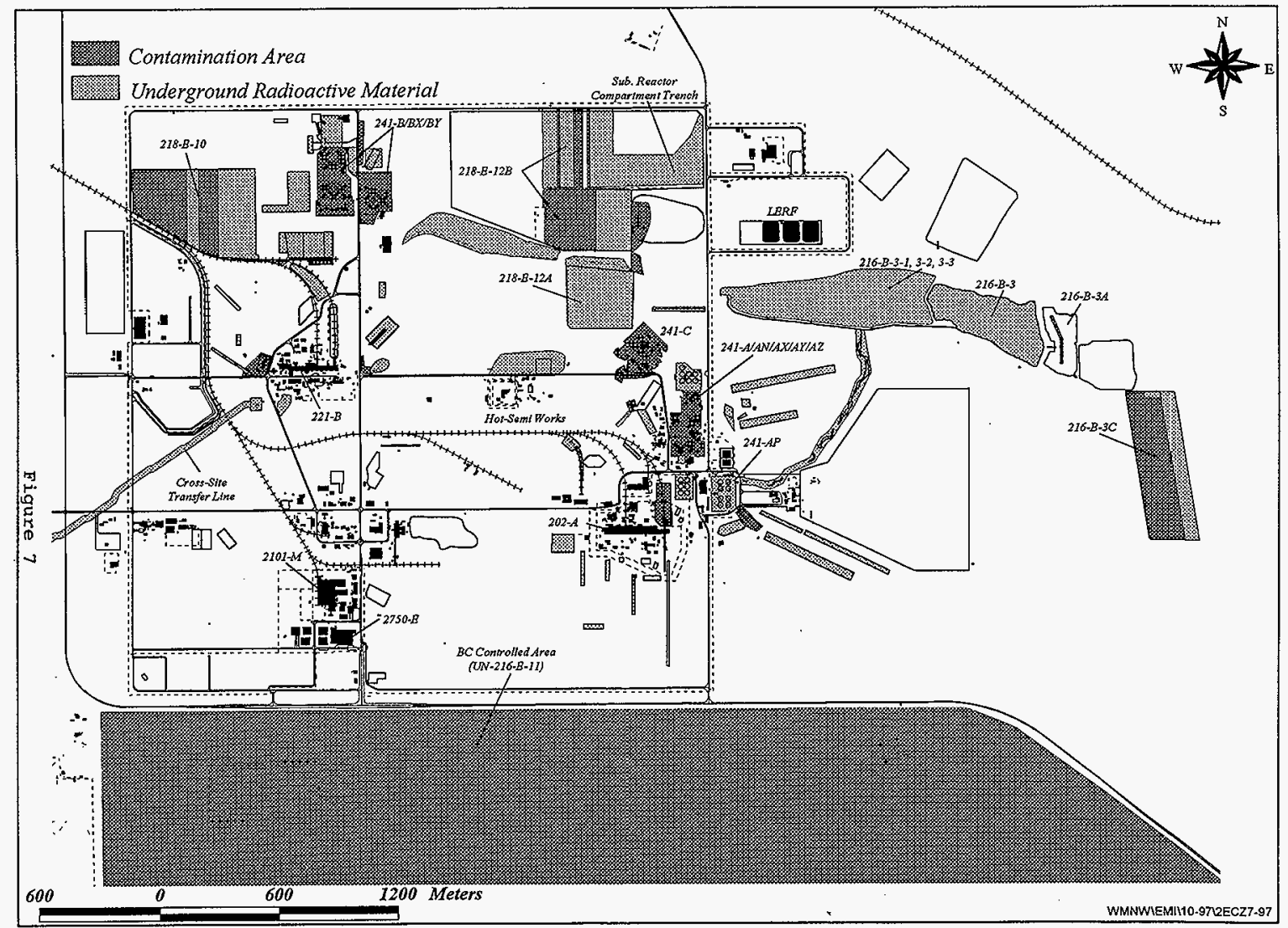




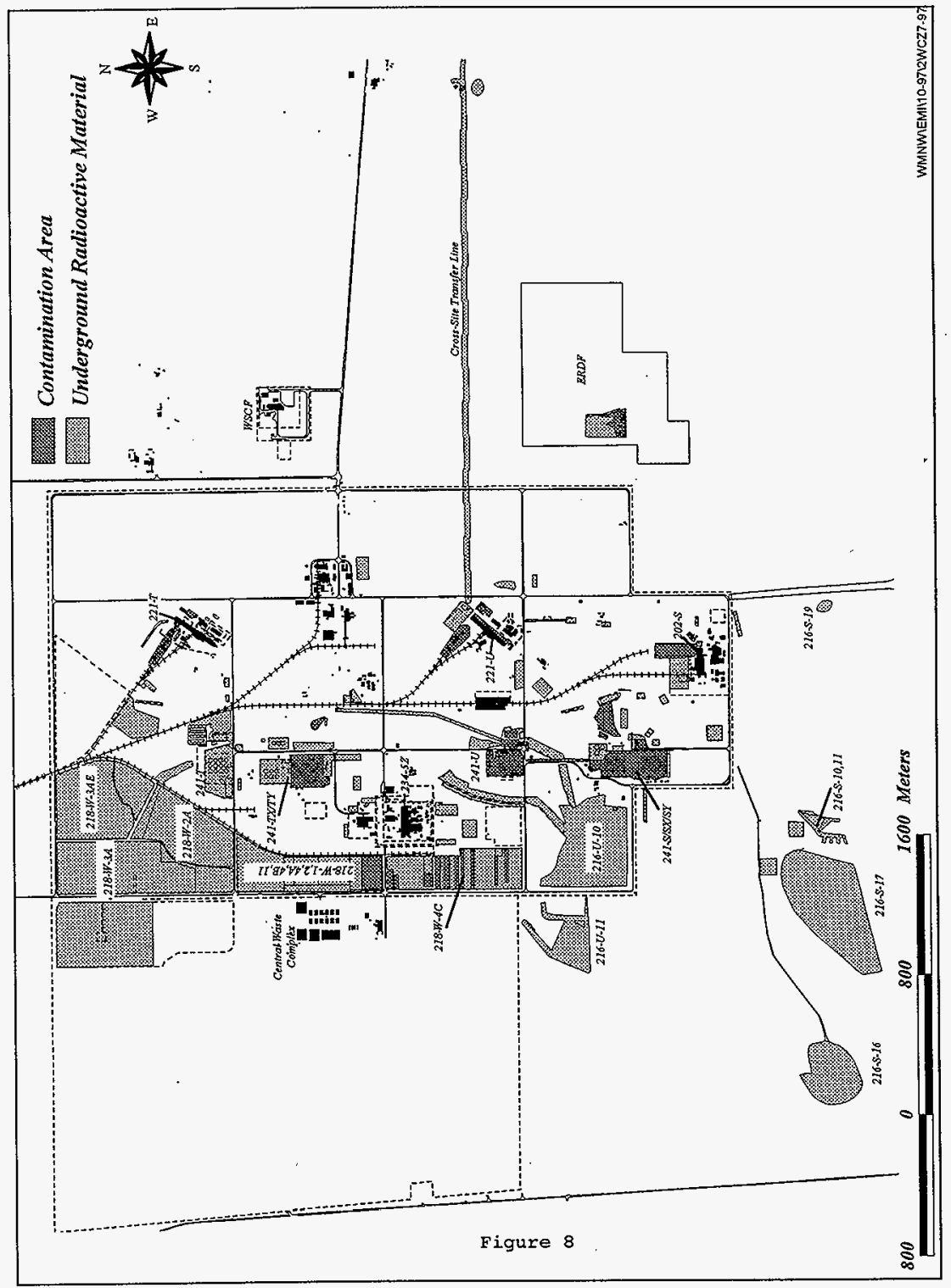




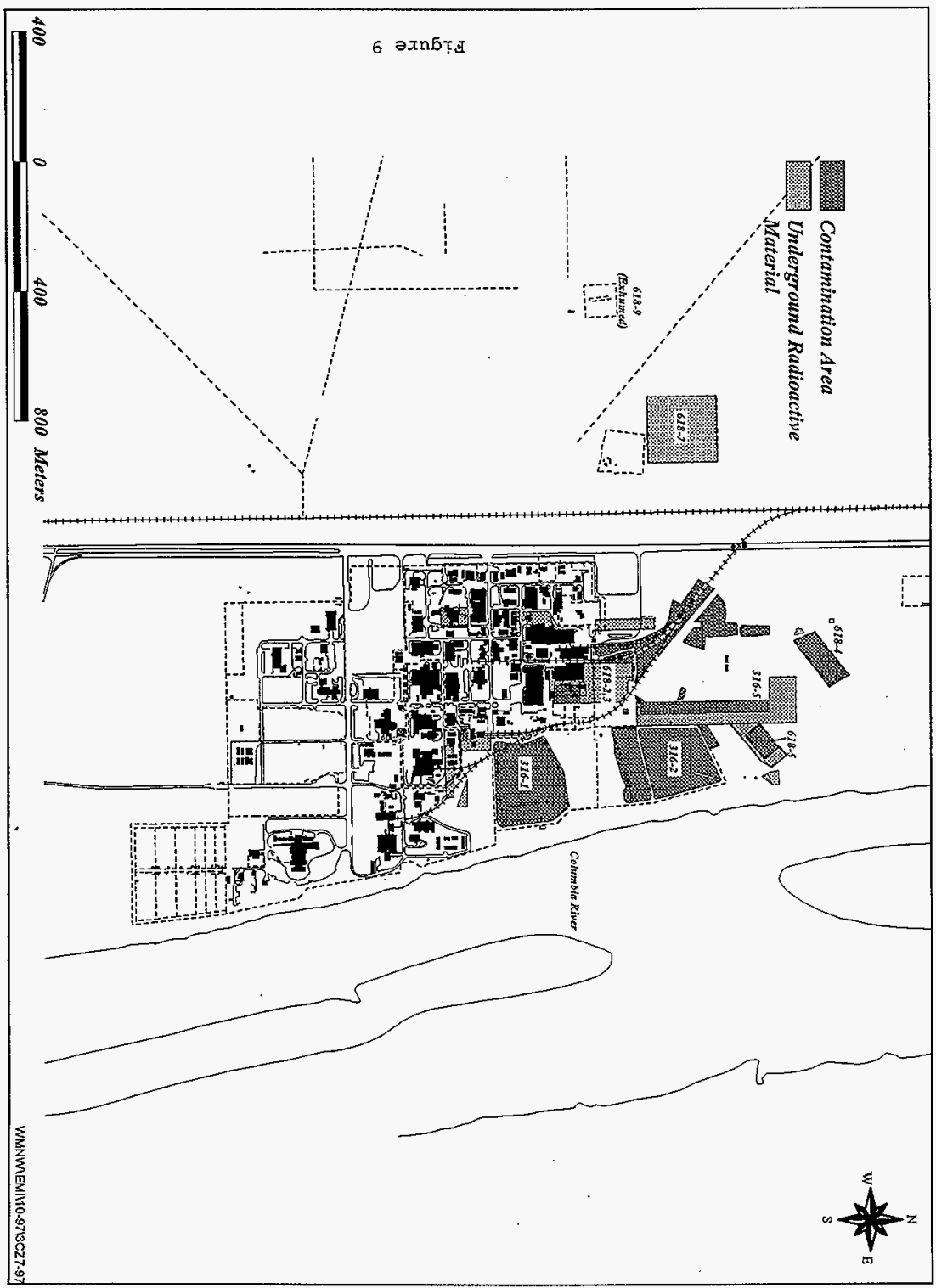


HNF-SP-0665-26

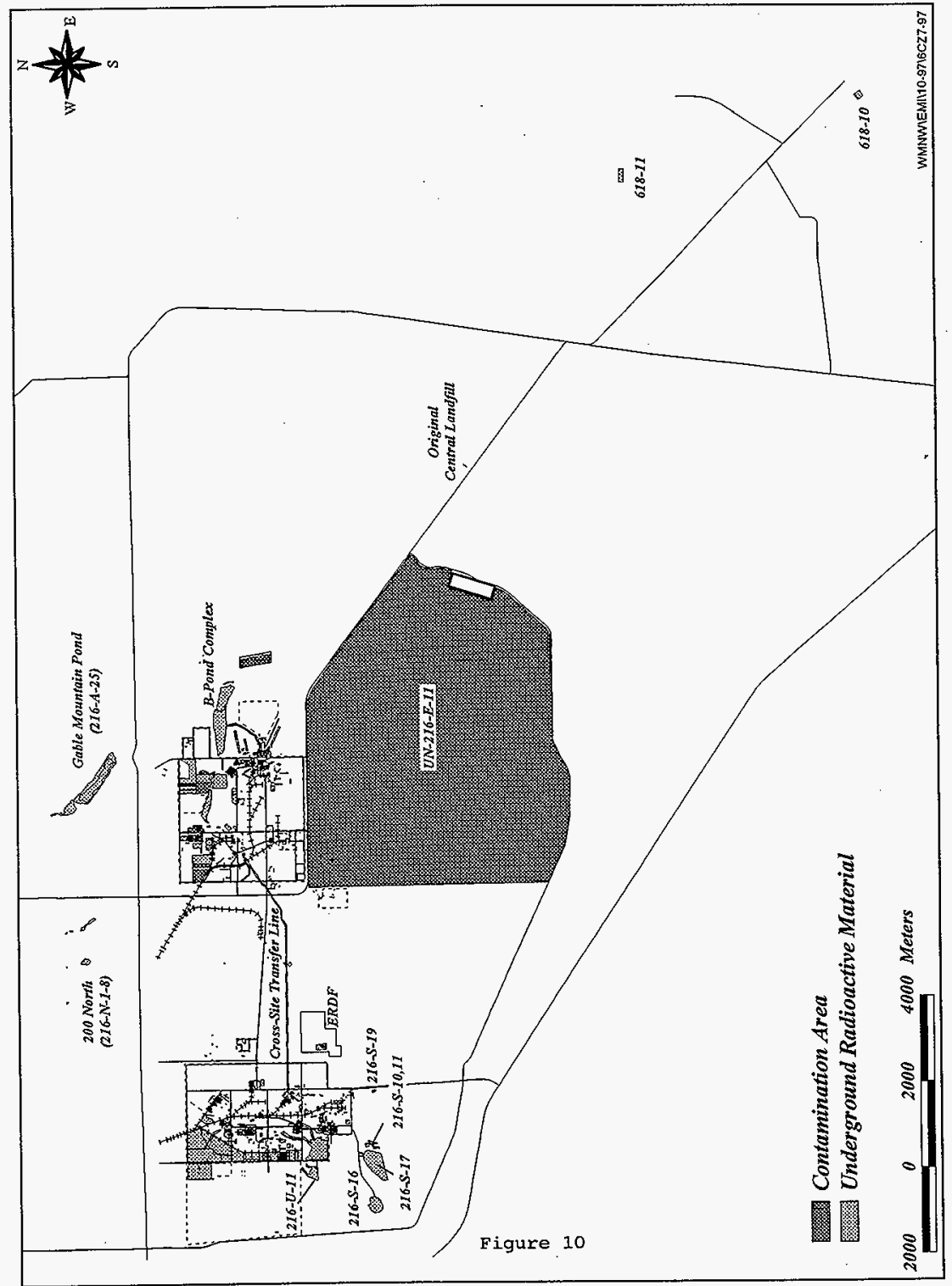


HNF-SP-0665-26

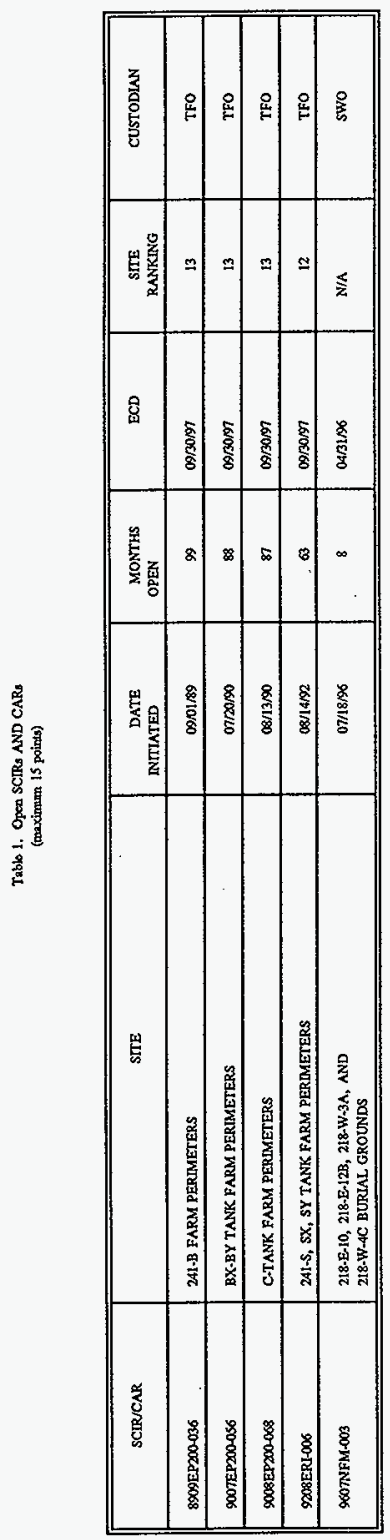




\subsection{PROGRAM DESCRIPTION}

\subsection{ENVIRONMENTAI RADIOLOGICAL SURVEX OBJECTIVES}

Environmental radiological surveys are performed to:

- Identify priorities for environmental cleanup or stabilization of surface contamination.

- Determine compliance with Department of Energy requirements and applicable policies and standards regarding operational control and environmental and radiological protection.

- Identify trends in radioactive contamination levels and contamination migration at waste sites and other radiological areas.

- Assess the surface integrity of solid and liquid waste disposal sites.

- Monitor for unplanned releases of radioactivity to the operations area environment.

\subsection{PRIORITY RANKING SYSTEM}

A numerical ranking system is used for sorting contaminated waste sites relative to environmental radiological concerns. This system provides a priority guideline to responsible landlords for clean-up or stabilization of contaminated/soil-contaminated areas.

A numerical value is assigned based on the level of contamination, site accessibility, and contamination mobility. Site histories are examined by reviewing past and present radiological surveys. Contamination levels from 1,000 counts per minute (cpm) to greater than $10 \mathrm{mrad} / \mathrm{hr}$ (as measured on Radiological Control's field survey instruments) are considered and assigned a numerical value of 1 (lowest value) to 5 (greatest value). Any removable alpha contamination will be considered a high priority and will receive a contamination value of 5 . Location is evaluated for accessibility. A restricted area would receive the lowest point value of 1 progressing up to a value of 5 where the public could have access. Mobility refers to contamination that can be or has a history of being transported from where it was originally identified to places outside of the posted radiological area. Fixed contamination would receive a value of 1 progressing to contamination that is blown by the wind or the result of biological uptake receiving a value of 5 . There is a maximum of 15 points possible for this ranking system.

It should be noted that this system is not intended to be a total risk assessment, but rather a way of communicating environmental significance to the landlords and their program offices. Other elements of the site clean-up process are considered such as costs, location, public/regulatory interest and engineering strategies before a site is actually remediated. 


\subsection{ENVIRONMENTAL STANDARDS}

Radiological survey data are used to determine compliance of Radioactive Waste sites with WHC-CM-7-5, Environmental Compliance, Section 6.0 (Rev. 3) and BHI-EE-02, Environmental Requirements, Section 7.0 (Rev. 0); requirements.

Applicable requirements include the following:

1. Engineered barriers shall be provided, where applicable, over the disposal site to inhibit radionuclide transport to the surface.

2. Inactive waste site boundaries shall be accurately and permanently marked with Hanford plant standard (AC-5-40) approved concrete marker posts. Sites never used and those that are no longer contaminated do not require marker posts.

3. Facility effluent lines which are potential discharge pointg shall be isolated, capped, or sealed off to prevent accidental releases to inactive sites. This shall be verified and documented.

4. Active and inactive waste sites shall be inspected and surveyed at least annually.

5. One or more of the following actions shall be taken when contamination of any type is detected (either new or in excess of action limits) to prevent the migration or mobilization of the contamination:

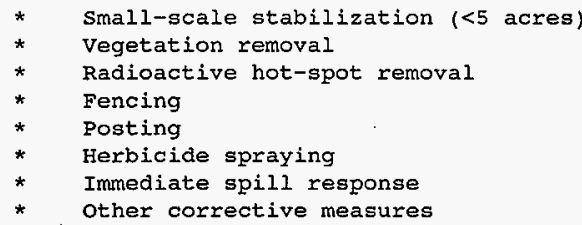

6. Information regarding all suspect waste sites or newly identified waste sites shall be provided for documentation into the Environmental Sites Database/Waste Identification Data system (ESD/wIDS).

7. Inactive waste sites shall be maintained to control deep-rooted vegetation that could provide transport of contamination to the surface through plant uptake. The application of herbicides or pesticides may be required. 
Environmental Monitoring and Investigations is responsible for:

1. Establishing radiological survey schedules of active and inactive radiological waste sites.

2. Conducting inspections of active and inactive waste sites to determine compliance with the physical and radiological requirements.

3. Compiling and maintaining copies of historical records, including radiological survey reports, compliance assessment reports (CARs), surveillance/compliance inspection reports (SCIRs), and other information for each active and inactive radioactive waste site.

4. Trending radiological data, and issuing reports on the status of radiological surveys and compliance assessments for active and inactive radioactive waste sites.

5. Reviewing any proposed activity, other than routine inspections, that may impact or may be impacted by any active and inactive waste site.

The above mentioned requirements apply to all active and inactive radioactive waste sites which include cribs, trenches, ditches, ponds, French drains, underground pipelines, burial grounds and other areas of concern such as the perimeters of tank farms and active burial grounds, and radioactive contamination due to spills or releases. Interiors of tank farms, active burial trenches and radiological areas where operations are ongoing are not included, because monitoring and tracking is done by the facility operations and other requirements are applicable to these areas.

In order to compare standards [as established in WHC-CM-7-5, section 6.0] and field instrument values, a conversion factor is necessary. This conversion factor has been established where $20,000 \mathrm{dpm}(2,000 \mathrm{cpm})$ are approximately equivalent to one millirem per hour for beta-emitting radionuclides. It must be understood that converting field instrument values, which include both beta and gamma energies, is approximate and does not allow for absolute precision. 


\subsection{SURVEY METHODS AND PROCEDURES}

Surveys documented by this report include road/railroad surfaces, cribs, underground pipelines, stabilized burial grounds, covered ponds and ditches, tank farm perimeters, active burial ground perimeters, unplanned release sites and other radiological areas. Methods and procedures for these surveys can be found in WHC-CM-7-4, operational Environmental Monitoring; HSRCM-1, Hanford Site Radiological Control Manual; and wHCIP-0718, Health Physics Technical Practices and Procedures.

\subsubsection{ROAD/RAILROAD SURVEYS}

Road and Railroad Surveys are conducted with a vehicle equipped with "high railers", which allows the vehicle to travel both on the roads or railroads, and sodium iodide detectors. The detector height is adjustable and the average survey height is six inches.

The vehicle is driven at less than five miles per hour. If activity above background is detected, the vehicle is stopped and a thorough survey is made with a portable count rate meter equipped with a pancake type probe to identify the extent of the contamination. Appropriate management is notified if road/railroad contamination is identified, and corrective actions are initiated.

\subsubsection{WASTE SITES AND OTHER RADIOLOGICAL AREA SURVEYS}

Surveys at waste sites and other radiological areas may be conducted with vehicles equipped with radiation detection instruments or with portable field instruments. Fieid instrument survey results are reported in disintegrations per minute (using a correction factor of $10 \mathrm{dpm} / \mathrm{cpm}$ ) as detected by using a Geiger-Muellex detector for beta/gamma radiation equipped with a pancake type probe. Alpha survey results are reported in disintegrations per minute (using a correction factor of $7 \mathrm{dpm} / \mathrm{cpm}$ ) as measured with a portable alpha meter (PAM). Surveys include the perimeter and portions of the ground surface of radiological areas. Wherever possible, smear surveys are made on the surface of exposed equipment and other hard surfaces within a radiological area. vegetation, animal burrows, and animal feces are also monitored to detect biological transport. Detailed survey practices and procedures are described in WHC-CM-7-4, Operational Environmental Monitoring; HSRCM-1, Hanford site Radiological Control Manual; and WHC-IP-0718, Health Physics Technical Practiceg and Procedures. 


\subsection{RADIOLOGICAL SURVEY RESULTS}

Al1 the routine environmental radiological surveys scheduled during the third quarter of 1997, were completed with the exception of REDox rail road cut. This site was not surveyed as the rail road cut was completely blocked with blown in vegetation. The ERC team requested that the second quarter routines be switched with the third quarter routines as there was a conflict with the vegetation management activities. These surveys were conducted as revised.

Surveys of active and inactive waste disposal sites included cribs, trenches, burial grounds, covered ponds and covered ditches. The survey schedule for environmental sites is outlined in WHC-CM-7-4, section 12, and in WHC-SP-0098-8, Rev. 0. Radiological surveys of the construction/remediation activities are performed by Environmental Restoration contractor and are not included in this report.

One hundred thirty three environmental radiological surveys were performed during the third quarter of 1997. Contamination above background levels was found at four of the surveyed active waste site areas and five of the inactive waste site areas. Contamination levels ranging from a low of $1,600 \mathrm{dpm}$ to a high of $600,000 \mathrm{dpm}$ were reported. Of the contamination' found, five sites were located in URM areas and four sites were located in a CA/SCA areas.

The contamination found in three of the URM areas was immediately cleaned up and no further action was required. The contamination found in the remaining two URM areas were posted and will require decontamination. Radiological Problem Reports were issued and the remaining sites were turned over to the landlord for further action.

The radiologically contaminated areas have been reposted to meet the new requirements as outlined in the Hanford site Radiological control Manual, HSRCM-1. The posting includes Contamination, High contamination (activity $>100,000 \mathrm{dpm} / 100 \mathrm{~cm}^{2} \mathrm{~B} / \mathrm{V}$ and/or $>10,000 \mathrm{dpm} / 100 \mathrm{~cm}^{2} \alpha$ ), Soil Contamination, Underground Radioactive Material, Radiological Buffer, and Radiation/High Radiation Areas. For continuity between quarterly reports issued in 1996 , the use of surface Contamination (SC) areas in this report includes Contamination, High Contamination, and soil contamination areas.

\subsection{RADIOLOGICAI SURVEY SUMMARY}

This report provides a synopsis of the radiological survey results conducted during third quarter of calendar year 1997. The stabilization efforts and release surveys for one waste site resulted in the down posting from $\mathrm{CA} / \mathrm{SC}$ to URM of 2.0 hectares $(5.0$ acres).

During the second quarter, stabilization efforts and a release survey for the 216-A-25 Gable Mountain Pond extension, discovered during 1996 with the Bechtel Nevada ariel radiological survey, was completed and the gite was radiologically down posted from CA/SC to URM.

While conducting radiological surveys, contaminated media was encountered and collected for analysis and/or disposal. Media found above actions levels defined in WHC-IP-0718, Health Physics Technical Practices and Procedures, are documented with a Radiological Problem Report and/or an 
occurrence Report. The samples that are deemed appropriate are sent in for analysis (Table 2). The results of these analysis can be found in the Hanford Site Near-Facility Environmental Monitoring Annual Report which is published in August of each year.

Abbreviations used in Table 2 are as follows:

NS - Not submitted for analysis.

NR - No activity recorded in the field.

$<D$ - Less than detectable with field instruments. 


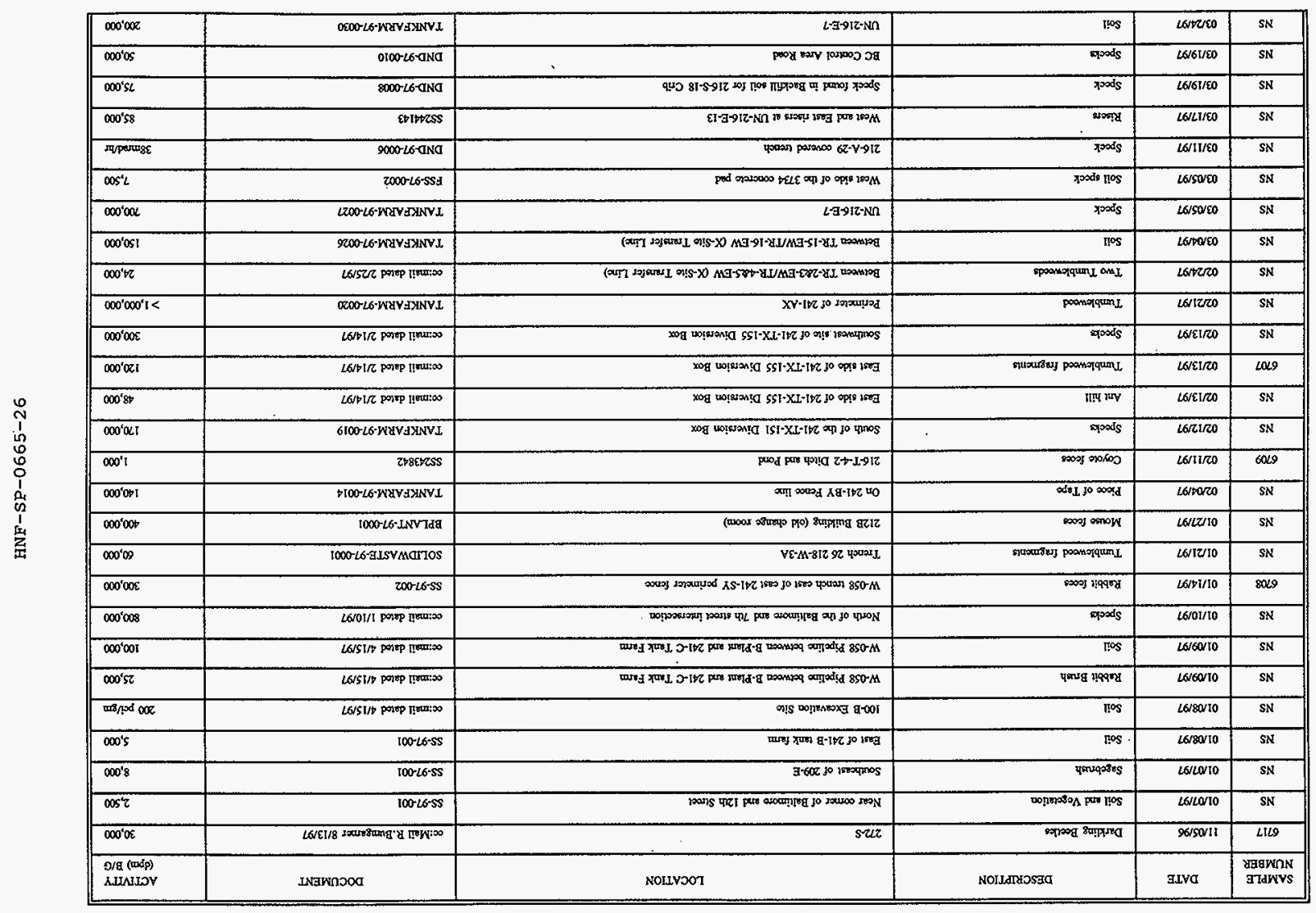

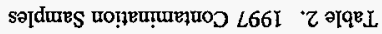


HNE-SP-0665-26

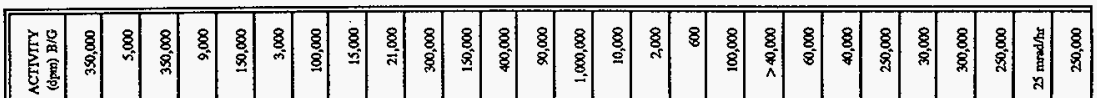

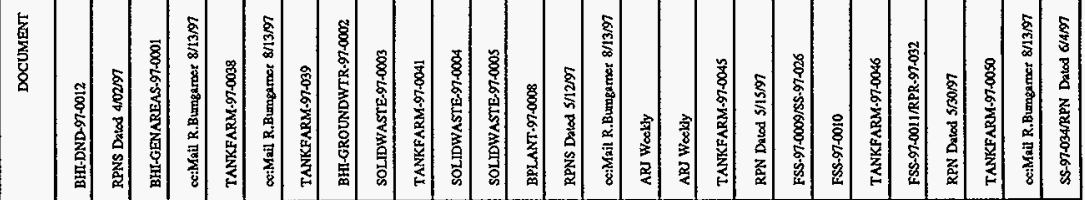



轂

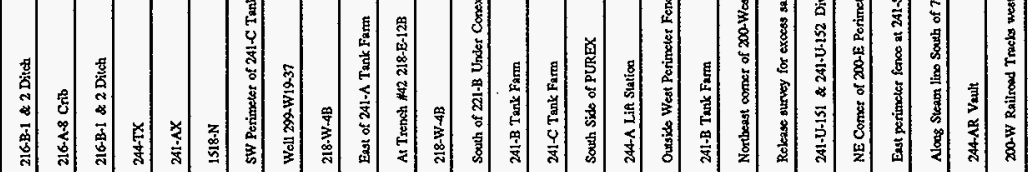

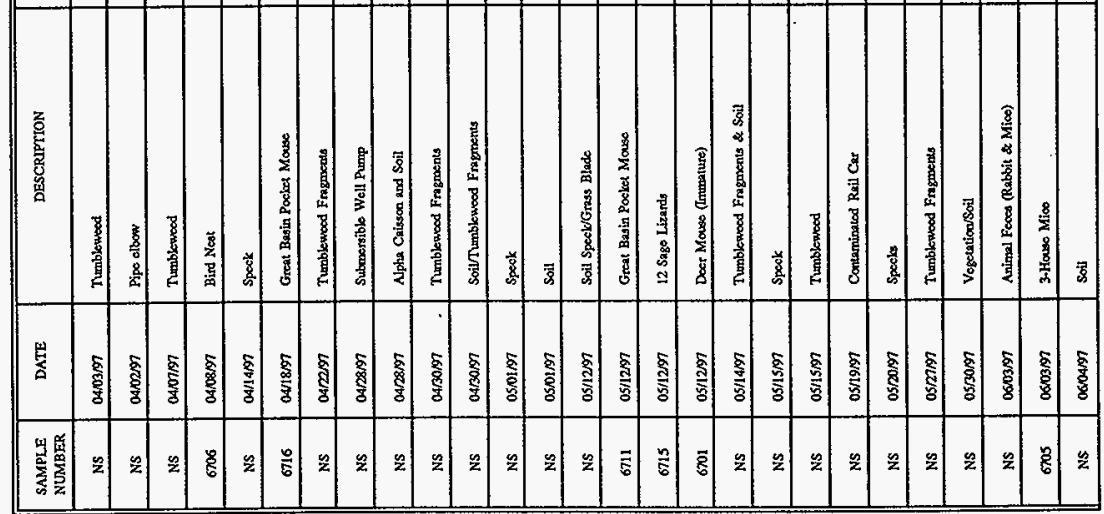


Table 2. 1997 Contamination Samples

\begin{tabular}{|c|c|c|c|c|c|}
\hline $\begin{array}{l}\text { SAMPLE } \\
\text { NUMBER }\end{array}$ & DATE & DESCRIPTION & LOCATION & DOCUMENT & $\begin{array}{r}\text { ACTIVIrY } \\
\text { (dpm) B/G }\end{array}$ \\
\hline NS & $0<05197$ & 10 Aress of Soll Spocks & 200-W Railnod Tracts North of soil found on 6/4/97 & FSS.97-0012 & 30,000 \\
\hline 669 & $\infty 6,05 / 97$ & Tumbleweod Fnigments & Da-E perimeter fenoe antisise Gato $\$ 10$ & FSS-97-0013 & 180,000 \\
\hline 6714 & $06,05 / 97$ & Mouse Nest & South of B-Plant Concx & coiMril R.Bumganes $8 / 3 / 3 / 97$ & 10,000 \\
\hline NS & 0609997 & Speck & $2706-r$ yeard & TPLANT-97.0010 & $\$ 5,000$ \\
\hline NS & 06,09197 & Dust Particlo & Railroud Tracies noth of $283-\mathrm{W}$ & RPN Datod 6/9/97 & 400,000 \\
\hline Ns & OSIIII97 & Speciss & 154-UX Diversion Box & TANKFARM-97-0053 & 450,000 \\
\hline 6700 & $06 / 1197$ & Mouso Feoses & R.R. Trache East of 218-W-4B Burial Ground & RPN Datod $6 / 11 / 97$ & 50,000 \\
\hline 6702 & $06 / 16997$ & Great Basin Pocket Mouse & $244 \wedge$ Lift Strtion & ce:Mril R.Bungarnes $8 / 33 / 97$ & 20,000 \\
\hline 6703 & $00 / 1699$ & Cotton Tail Rebbit & $244 \mathrm{~A}$ Lift Station & $\infty:$ Mail R.Bumgamer 8/13/97 & $<\mathrm{D}$ \\
\hline NS & $+\infty 18 / 97$ & Dust Particle & 216.5 .25 & RPN Dalod $618 / 97$ & 150,000 \\
\hline 6713 & $06 / 19 / 97$ & Doer Mossos & 2A1-s Tank Farm Weat Perimelet & RSR SS-24S029 & 8,000 \\
\hline 6204 & O6RAM97 & Dest Mouse (Immature) & 244 A Lift Station & c:Mail R.Bumsumer 8/13/97 & 8,000 \\
\hline NS & $0 \times 26997$ & Tunbleweod Fragments & UN-216-E-20/21 & Fss-97-0015 & 350,000 \\
\hline NS & $06 / 30197$ & Tumbleveed Fragments & Insido 200-E at LERF Loop Road & FSS-97-0016 & 400,000 \\
\hline NS & 0707997 & Tumbleveed & Outsite ine cest fence lise of $241-\mathrm{NX} / \mathrm{AZ}$ & TANKFARM-97-0057 & 600,000 \\
\hline NS & $07 / 17 / 97$ & Fletbed Rail Car HO-10A-3407 & Contamination found during exocss sate vurvey & FSS-97-0017 & 11,000 \\
\hline NS & $03 / 14 / 97$ & Ans mound & 25 foot NW of 216-Z9B Building & CC:mail dated $7 / 4 \% 7$ DPE & 40,000 \\
\hline NS & $07 / 1797$ & Mouse & 100-K Basins & Telecosa from Tony Dazo & 4,000 \\
\hline Ns & $0721 / 97$ & Tumblewood Frapments & Along $23 \mathrm{rd}$ Street in $200 \mathrm{~W}$ & $\mathrm{CC}:$ Mail detod 7R1/O6 DPE & $\$ 0,000$ \\
\hline 6712 & 0072297 & 2-Dee: Miee & MO-031 east of PFP & RSR SS-24S267 & 10,000 \\
\hline NS & $07 / 23 / 97$ & Flatbed Treiler HO-64-15325 & Contumination found during axecess sele survey & FSS: $-97-0018$ & 310,000 \\
\hline 6710 & onrasm & Great Basin Pocket Mise & 6290-E Rigger's Lot & RSR SS-2ASS & 4,000 \\
\hline NS & $07 / 28 / 97$ & Turableweod & Eest of $241-A Z$ & TANKFARM-97-0059 & 50,000 \\
\hline NS & 0728197 & Speck & South of the risdle change trailer $241 . C$ Tenk Furm & TANKFARM.97-0050 & $\$ 0,000$ \\
\hline Ns & $07 / 28 / 97$ & Driod wegetstion & In treoch 1422 in 218-E.12B Burial Grome & SOLDWASTEM7-0010 & 100,000 \\
\hline Ns & $07 / 25 / 97$ & Asptalv/roedway & Roudway at comer of AlasterGinko 300 Area & FSS-97-0019 & $\$ 0,000$ \\
\hline Ns & $07 / 2997$ & Vesetation & 1301-N Vegetation Semples 46886 \& 667 & RSR SS-24S291 & 35,000 \\
\hline
\end{tabular}


Table 2. 1997 Contamination Samples

\begin{tabular}{|c|c|c|c|c|c|}
\hline $\begin{array}{l}\text { SAMPLE } \\
\text { NUMBER }\end{array}$ & DATE & DESCRIPTION & LOCATION & DOCUMENT & $\begin{array}{r}\text { ACTINTYY } \\
\text { (dpm) B/G }\end{array}$ \\
\hline NS & $0 \$ 01 / 97$ & Soil & At the base of 296-E-10 Stack & WESF-97-0006 & 75,000 \\
\hline NS & $08 / 1297$ & Pebblo (gravel) & Shoulder of sood 10 Alsshe and Ginko Strocts & FSS-97-0021 & 20,000 \\
\hline NS & $08 / 13 / 97$ & Flatbod Trailer & 1100 Area priot to offisite shiponent & FsS. -97.0022 & $1,600,000$ \\
\hline NS & $08 / 1297$ & Soil & Sanjiscy Tibo Ficld & BPLANT-97-0012 & 75,000 \\
\hline NS & $08 / 19197$ & Paint Chip & UN-216-W-23 (Ounotdo the 211-U Tank Farm Perimeter) & CC:Mail Seved 8/19,97 & 15,000 \\
\hline Ns & $08 / 18 / 97$ & Soil Speciss & 152-TX Perimaler & TANKFARM-97-0059 & 150,000 \\
\hline Ns & $08 / 2297$ & Specik & Under peinced surfece of 307 Besins & 300LEF-97-0004 & 750,000 \\
\hline NS & $08 \pi 2697$ & Mouso Urino & Underoide anox H64-15027 \& Cosoreto Pad & s5.97-0s0 & 95,000 \\
\hline NS & $08 / 2697$ & Turbleweed Fragmeds & Trench 194 in $216-\mathrm{E}_{-128}$ & SOLIDWASTE-97-0011 & 250,000 \\
\hline NS & 090899 & Mouso Foces & 2711-E Vehiele Maintenanoo Facility (veliclo 1C-439) & CC:Mail dated 908/97 & 55,000 \\
\hline Ns & $09 / 11 / 97$ & soil & 202s Rediation Muterial Area & ANALI_AB-97.0026 & 85,000 \\
\hline
\end{tabular}

Nocs: Activity is reportod in disintegrations per minuto belw/gamma. 
HNE-SP-0665-26

\subsection{SURVEILIANCE/COMPLIANCE REPORTS CLOSED}

No SCIRs were closed during the third quarter of 1997.

\subsection{STATUS OF OPEN SURVEILUANCE AND COMPLIANCE REPORTS}

Five sCIRs, from past activities, remained open at the end of the third quarter of 1997. These reports are summarized on Table 1 to include the referenced site number, priority ranking points (maximum of 15 points based on contamination levels, location and mobility), responsible custodian, SCIR report number, and estimated completion date.

Abbreviations used on Table 1 include:

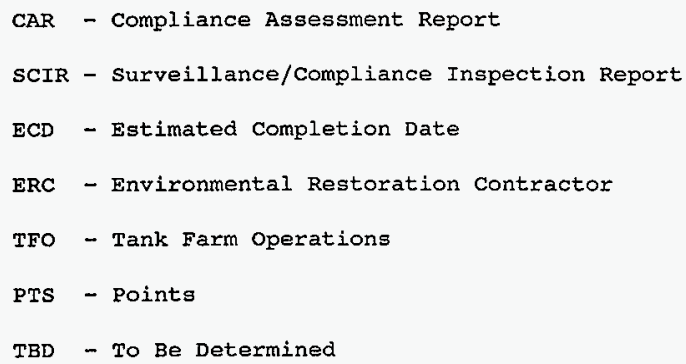




\subsection{SURAARY}

All the routine outdoor radiological surveys were completed during third quarter of calendar year 1997 in the 100, 200-East/West, 300 and 600 areas with the exception of the REDOX rail road cut. Physical constraints prevented this scheduled survey.

The second quarter routine surveys were performed during the third quarter due to requested schedule changes by the ERC team.

No SCIRs were closed (Section 3.2 )

Five SCIRs remain open. Open reports have been addressed and clean-up plans with completion dates are being developed or are to be provided to Environmental Monitoring and Investigations.

\section{RADIOLOGICAL POSTING CHANGES}

An on going effort to stabilize and/or clean up areas of known contamination and to down post or release these areas from posting is being performed by the Environmental Restoration Contractor and by the facility managers. In the third quarter of 1997, 2.0 hectares (5.0 acres) were stabilized and down posted from CA/SC to URM. From the beginning of 1991 through the end of the third quarter of 1997, 560 hectares $(1,384$ acres) have been stabilized and down posted to URM with 4,006 hectares $(9,893$ acres) remaining to be stabilized and down posted or cleaned up and released. Table 3 shows the downward trend of the contamination status during this time period.

Radiological posting changes, by waste site, noted during the third quarter of calendar year of 1997 are as follows:

The surface soil contaminated section of the 216-A-25 (Gable Mountain Pond) extension discovered during the radiological mapping fly over in 1996, was cleaned up and down posted from CA/SCA to URM, 2.0 hectares (5.0 acres).

The Environmental Restoration Disposal Facility (ERDF) started receiving waste in July 1996. Currently the ERDF consists of two cells, measuring $230 \mathrm{~m}$. (750 ft.) wide by $305 \mathrm{~m}$. (100 ft.) long and $24 \mathrm{~m}$. ( $80 \mathrm{ft}$. ) deep, capable of holding 1.4 million tons of waste material. A milestone was reached in september 1997 with the ERDF having received 500,000 tons of contaminated waste. The waste came from remediation activities in the $100 \mathrm{~B} / \mathrm{C}, 100 \mathrm{D}$, and 300 Areas. Mapping the changes in contamination and underground radiation areas in the ERDF will be conducted semiannually. Currently there are 13.9 hectares (34.4 acres) available for waste disposal. This is the first quarter that the posting changes have been added to this report, with the URM area being reported as 1.9 hectares ( 4.8 acres) and the contamination area being reported as 1.1 hectares (2.7 acres). 
Table 3. Outdoor Contamination Status 1991 through 1997 [approximate surface area in hectares (acres)]

\begin{tabular}{|l|c|c|c|c|c|c|c||}
\hline Hanford Site Area & 1991 & 1992 & 1993 & 1994 & 1995 & $1996^{a}$ & 1997 \\
\hline 100 Areas & $65(160)$ & $65(160)$ & $65(160)$ & $63(155)$ & $52(129)$ & $47(116)$ & $47(116)$ \\
\hline 200 Areas & $157(389)$ & $133(329)$ & $129(318)$ & $105(261)$ & $92(228)$ & $99(245)$ & $89(220)$ \\
\hline 300 Areas & $18(45)$ & $18(45)$ & $18(45)$ & $21(52)$ & $21(52)$ & $20(49)$ & $20(49)$ \\
\hline $600 \&$ BC Control Areas & $1,465(3,620)$ & $1,060(2,620)$ & $1,063(2,627)$ & $1,063(2,627)$ & $1,063(2,627)$ & $3,850(9,513)^{\mathrm{b}}$ & $3,850(9,513)^{\mathrm{c}}$ \\
\hline Totals & $1,705(4,214)$ & $1,276(3,154)$ & $1,275(3,150)$ & $1,320(3,261)$ & $1,275(3,150)$ & $4,016(9,923)$ & $4,006(9,898)$ \\
\hline
\end{tabular}

Note: There are some discrepancies as to the total acreage reported and areas remediated. This is due to the gained accuracy in measurement from the exclusive use of GPS equipment for the measurement of the contaminated surface areas.

- The large increase in $600 \& \mathrm{BC}$ Control Areas is due to increased acreage posted around the BC Control Area.

- The ERDF has been added during the 3rd quarter of 1997, 1.9 ha (4.8 acres). 
DISTRIBUTION

- Number of Copies

ONSITE

WASTE MANAGEMENT FEDERAT SERVICES, INC, NORTHWEST

19
J. J. Dorian
H1-13
A. R. Johnson
H1 13
B. M. Markes (5)
S. M. Mckinney (12)
H1-13
H1- 13

U.S. DEPARTMENT OF ENERGY - Richland

5
G. M. Bell
A5-52
C. R. Briggs
A $5-55$
S. E. Clarke
A5-15
J. B. Hall
A5 -15
D. C. Ward
A5-15

BECHTEL HANFORD, INC.

15
A. I. Davis
$x 2-17$
L. A. Dietz
HO-2O
R. G. Egge
T7-05
W. M. Hayward
T7-05
J. E. Hodgson
T7 -12
R. A. Hughes
H0-16
พ. L. Osborne
T7-05
T. L. Lafreniere
$\mathrm{X} 0-23$
R. J. Landon
HO-O2
G. B. Mitchem
H0-17
J. E. Parsons
$\mathrm{x} 0-23$
K. A. Smith
$\times 7-75$
C. D. Wade
T7-15
C. R. Webb
H9-10
J. P. Zoric
$\times 5-57$ 


\section{Number of Copies}

3

\section{BEW HANEORD COMPANY}
S. E. Killoy
D. J. McBride
s4-66
R. J. Thomas
T5-54
I $4-20$

3

DE\&S HANFORD, INC.
D. I. Chase
M. Kaviani
$\mathrm{x} 3-85$
$x 3-60$
$\times 3-79$

2

\section{DYNCORP}

H. A. Besel

R. A. Schieffer

T1-27

T1-27

ENVIRONMENTAL MANAGEMENT, INC.

2
R. F. Giddings
G6-82
R. C. RoOs
G6-82

FLUOR DANIEL HANEORD, INC.

2
J. A. Bates
H6-23
D. P. Ellingson
T1-27

\section{FLUOR DANIEL NORTHWEST}

1
P. I. Thakkar
G3-08

LOCKHEED MARTIN HANFORD CORP.

9
D. Alison
J. M. Barnett
S. L. Bump
C. L. Caldwell
D. A. De Lucchi
M. I. Dexter
R. E. Elder
R. K. P'Pool
o. L. Rasmussen

S5-03
T4-08
L5-65
S5-07
T4-08
R1-51
S7-07
S5-03
R1-51 
DISTRIBUTION (continued)

Number of Copies

LOCKHEED MARTIN SERVICES

2

Document Process Center

Central Files

A3-94

B1-07

PACIFIC NORTHWEST LABORATORY

2
R. I. Dirkes (2)
K6-75

WASTE MANAGEMENT FEDERAL SERVICES OF HANFORD, INC.

5
B. J. Broomfield
T3-04
L. P. Diediker
H6-36
D. I. Mitchell
H6-29
R. D. Pierce
T3-04
G. C. Triner
T3-05 